\title{
Food chain approach to lowering the saturated fat of milk and dairy products
}

Article

Accepted Version

Kliem, K. E., Humphries, D. J., Markey, O., Vasilopoulou, D., Fagan, C. C., Grandison, A. S., Jackson, K. G., Todd, S., Givens, I. D. and Lovegrove, J. A. (2019) Food chain approach to lowering the saturated fat of milk and dairy products. International Journal of Dairy Technology, 72 (1). pp. 100-109. ISSN 1364-727X doi: https://doi.org/10.1111/1471-0307.12564 Available at https://centaur.reading.ac.uk/78243/

It is advisable to refer to the publisher's version if you intend to cite from the work. See Guidance on citing.

To link to this article DOI: http://dx.doi.org/10.1111/1471-0307.12564

Publisher: Wiley-Blackwell

All outputs in CentAUR are protected by Intellectual Property Rights law, including copyright law. Copyright and IPR is retained by the creators or other copyright holders. Terms and conditions for use of this material are defined in the End User Agreement.

\section{www.reading.ac.uk/centaur}

\section{CentAUR}


Central Archive at the University of Reading

Reading's research outputs online 
2

K. E. Kliem ${ }^{1 *}$, D. J. Humphries ${ }^{1}$, O. Markey ${ }^{2,3,4}$, D. Vasilopoulou ${ }^{2,3}$, C. C. Fagan ${ }^{3}$, A. S.

$6{ }^{1}$ Animal, Dairy and Food Chain Sciences, School of Agriculture, Policy and Development,

7 University of Reading, $U K, R G 66 A R$

$8 \quad{ }^{2}$ Hugh Sinclair Unit of Human Nutrition and Institute for Cardiovascular and Metabolic

9 Research (ICMR), University of Reading, UK, RG6 6AP

$10 \quad{ }^{3}$ Food and Nutritional Sciences, School of Chemistry, Food and Pharmacy, University of

11 Reading, UK, RG6 6AP

${ }^{4}$ Present address: School of Sport, Exercise and Health Sciences, Loughborough University,

Loughborough,UK, LE11 3TU

${ }^{5}$ Department of Mathematics and Statistics, School of Mathematical, Physical and

Computational Sciences, University of Reading, UK, RG6 6AX

${ }^{6}$ Institute for Food, Nutrition and Health, University of Reading, UK, RG6 6AR

Reading, Earley Gate, PO Box 237, Reading RG6 6AR, tel: +44(0)118378 8481,

\section{k.e.kliem@reading.ac.uk}


ABSTRACT

27

Lactating cow diets were supplemented with high oleic acid sunflower oil over two production periods spanning two years, to modify the milk fat, partially replacing saturated fatty acids (SFA) with cis-monounsaturated fatty acids (MUFA). The resulting milk was used for ultrahigh temperature (UHT) milk, butter and Cheddar cheese production, and fatty acid profiles were compared with those of conventionally-produced products. Fat from products made with modified milk had lower SFA and higher cis- and trans-MUFA concentrations than that of conventional products. This was consistent over production periods, demonstrating that this food chain approach could be adopted on a wider scale.

Keywords: Bovine milk, fatty acids, lipids, milk processing

\section{INTRODUCTION}

Milk and dairy products are a major source of fat and fatty acids (FA) in the UK adult diet, contributing to $18 \%$ total fat, $28 \%$ saturated fatty acid (SFA), $38 \%$ trans fatty acid (TFA) intake (Bates et al., 2016) and $12 \%$ cis-monounsaturated fatty acid (MUFA) intake (Hobbs, personal communication). At the population level total SFA intake exceeds current recommendations (12.1\% total energy intake [EI]; Bates et al., 2016 vs <10 \% total EI; WHO, 2010). A reduction in dietary TFA from industrially hydrogenated food sources has led to an increase in the contribution of these FAs from dairy products but overall TFA consumption has declined (Henderson et al., 2003; Bates et al., 2016) and is below the maximum recommended intake of $2 \%$ total energy (SACN, 2007).

Replacing dietary SFA with cis-MUFA and cis-polyunsaturated fatty acids (PUFA) has been shown to reduce cardiovascular disease (CVD) risk factors, including fasting serum total and 
51 low density lipoprotein-cholesterol concentrations and total:high density lipoproteincholesterol ratio (Vafeiadou et al., 2015). The most effective means of replacing SFA with unsaturated FA in milk fat is by altering the dairy cow diet (Kliem \& Shingfield, 2016). Due to the more extensive rumen biohydrogenation of dietary PUFA compared with cis-MUFA (Shingfield et al., 2008), and the greater proportion of cis-MUFA compared with PUFA in milk fat (Kliem et al., 2013), replacement of SFA with cis-MUFA offers a greater potential for SFA reduction in milk fat. Relatively few studies have assessed the impact of consuming dairy products modified using this dietary strategy (replacing milk SFA with either MUFA or PUFA) on cardiovascular health outcomes in humans (Livingstone et al., 2012). Some of these studies used only butter as the test dairy product, thus not representing the nutritional composition of a range of dairy products and food matrices (Livingstone et al., 2012). Two studies (Noakes et al., 1996; Seidel et al., 2005) included a range of dairy products modified by changing the cow diet in their interventions, but the human interventions only lasted for relatively short periods of time (up to three weeks) and involved small numbers of participants. It is not known whether the FA composition of milk and dairy products produced by changing the cow diet would be consistent over longer periods of time, especially as milk FA response to dietary oilseeds appears to vary according to differences in other dietary nutrients (Lerch et al., 2012a).

The main objectives of this study were twofold; firstly to identify whether UHT milk, butter and Cheddar cheese could be produced with the same FA profile over a two-year period, from milk produced using an oleic-acid rich supplementation strategy. This utilised a high oleic acid (cis-9 18:1) sunflower oil to maximise the replacement of SFA with MUFA, after previous research highlighted the potential of these oils (Loor et al., 2002; Kliem et al., 2011). The second objective was to compare the FA composition of the modified dairy products with conventional products containing FA profiles typical of UK retail milk during winter months 
(average SFA $71.5 \mathrm{~g} / 100 \mathrm{~g}$ total FA, cis-MUFA $21.2 \mathrm{~g} / 100 \mathrm{~g}$ FA; Kliem et al., 2013), and for this to be consistent across products.

\section{MATERIALS AND METHODS}

\section{Production of modified milk}

Between December 2013 and May 2015, groups of multiparous Holstein-Friesian cows were fed a diet which resulted in modified milk. For the purposes of the human intervention trial that this study formed part of (Markey et al., 2017), milk production was divided into two periods; Production period 1 (P1) took place between December 2013 and September 2014, involving a total of 58 cows (mean \pm standard error parity $4.0 \pm 0.12$; milk yield at start $35.0 \pm 0.77$ litres/day, and days in lactation $181 \pm 7.7$ ), producing a total of approximately 12,500 litres of milk which were used to produce modified UHT milk, butter and cheese. Production period 2 (P2) took place between November 2014 and May 2015, involving a total of 41 cows (mean \pm standard error parity $4.0 \pm 0.12$; milk yield at start $33.4 \pm 0.91$ litres/day, and days in lactation $205 \pm 7.2$ ) producing a total of 16,350 litres of milk. Cows selected to produce modified milk were adapted to a total mixed ration (TMR) diet, an example of which is presented in Table 1. Dietary ingredients were replicated for each production batch. The diet had a forage:concentrate ratio of 50:50 on a DM basis, with the forage consisting of maize silage, grass silage, grass hay and wheat straw. The diet was supplemented with $43 \mathrm{~g} / \mathrm{kg}$ dry matter (DM) of high oleic acid sunflower oil (AAK Ltd., Hull, East Yorkshire, HU9 5PX, UK) so that it would supply a cow consuming $23 \mathrm{~kg}$ DM per day with $1 \mathrm{~kg}$ oil. The cows were adapted to this diet for a period of four weeks before any milk collection was made. Following this adaptation period, subsamples of modified milk were taken and preserved with potassium dichromate ( $1 \mathrm{mg} / \mathrm{ml}$; Lactabs; Thompson and Capper, Runcorn, UK) for milk compositional 
analysis. A further subsample was frozen to measure the FA profile prior to product manufacture.

\section{Manufacture of dairy products}

UHT Milk Processing. UHT milk, i.e. both modified and conventionally-produced milk, was produced three times, twice during P1 and once during P2. The first P1 production run was carried out at Reaseheath College (Nantwich, UK) with the remaining production runs carried out at Frampton's Ltd (Shepton Mallet Somerset, UK). Raw conventional milk was provided by Arla Foods UK (Taw Valley Creamery, North Tawton, UK), and represented retail milk with a typical UK winter dairy FA profile. Conventional milk was standardised to match the fat content of the modified milk using skimmed milk provided by A.E Rodda \& Son Ltd., (Redruth, Cornwall, UK), for the purposes of the human intervention study. Raw conventional milk was pumped to a tank and skimmed milk, at the level required to match the low SFA milk fat content, was added. The milk was agitated in the tank for 5 minutes and a sample removed and analysed to ensure the fat content was correct. UHT processing was carried out in a pilot scale UHT plant. The milk was preheated to $85^{\circ} \mathrm{C}$ using a plate heat exchanger and homogenised. The milk was then heated to $142^{\circ} \mathrm{C}$ for 5 seconds using direct steam infusion and cooled to $15^{\circ} \mathrm{C}$ and aseptically packaged into $5 \mathrm{~kg}$ aseptic bags (Reaseheath) or $330 \mathrm{ml}$ aseptic cartons (Framptons). All UHT milk was stored at $4^{\circ} \mathrm{C}$ until required.

Cheddar cheese processing. Conventional Cheddar cheese was provided by Arla Foods UK (Taw Valley Creamery), to represent retail mild (3 month) Cheddar cheese with a typical UK winter dairy FA profile. Modified Cheddar cheese was manufactured at the University of Reading Pilot Plant (Reading, UK). Both cheese types were produced only once during P1 and P2. The processing parameters for the modified cheese were selected to mimic the commercial 
process used at Arla. Modified raw milk was pasteurised at $73^{\circ} \mathrm{C}$ for 15 seconds in a high-

127

128 temperature short-time pasteuriser (flow rate $300 \mathrm{~L} / \mathrm{h}$ ) using a plate heat exchanger. The milk was cooled to $32^{\circ} \mathrm{C}$ and transferred to $100 \mathrm{~L}$ cheese vats. Starter culture (R 604, Chr. Hansen) was added $(0.15 \mathrm{~g} / \mathrm{L})$ to the vat and allowed to ripen under stirring for 50 minutes. Enzyme (CHY-MAX, Chr. Hansen) was added $(0.24 \mathrm{ml} / \mathrm{L})$ and stirred for a further 3 minutes, before the stirrers were removed. Cutting time was 40 minutes after enzyme addition and was visually confirmed by the cheesemaker. The coagulum was cut by hand using coagulum cutting knives. Stirring commenced, and the temperature was increased slowly until it reached $38^{\circ} \mathrm{C}$; this scalding process continued for $1 \mathrm{~h}$. Whey was subsequently drawn off the cheese vat. The resulting curd underwent a cheddaring process by piling and turning the curd 4 times. The curd was then milled using a cheese mill and dry salted $(0.02 \mathrm{~kg} / \mathrm{kg})$ and placed into a stainless steel cheese mould. The mould was placed in a horizontal cheese press and pressed at $7 \mathrm{kPa}$ overnight. The next day the cheese was vacuum packed and placed in an $8^{\circ} \mathrm{C}$ ripening room for three months. After ripening, cheese was apportioned into $350 \mathrm{~g}$, vacuum packed and stored at $2^{\circ} \mathrm{C}$.

Butter processing. Conventional butter was provided by Arla Foods UK (Taw Valley Creamery) from winter butter stocks during P1 and P2. Modified P1 butter was manufactured at Reaseheath College (Nantwich, UK) and modified P2 butter was manufactured at Ty Tanglwyst Dairy (Bridgend, South Wales). Two batches of modified butter were manufactured in each period. In both cases the cream was separated from the milk using a disc bowl separator, pasteurised, and aged at $4^{\circ} \mathrm{C}$ overnight. The cream was transferred to a churn and churned until butter grains were formed. The buttermilk was drained off and the butter grains were further worked to create a continuous emulsion. Salt was then added $(1.7 \mathrm{~g} / 100 \mathrm{~g})$ and the butter was 
further worked to ensure even distribution of the salt. The butter was apportioned into $250 \mathrm{~g}$, packaged in butter wrap and stored at $-20^{\circ} \mathrm{C}$ until required.

\section{Chemical analysis of milk and dairy products}

A sample of high oleic acid sunflower oil used during P1 and P2 and subsample of the TMR diet were analysed in duplicate for FA profile using a modified version of the one step transesterification method of Sukhija \& Palmquist, (1988). Briefly, $50 \mathrm{mg}$ oil or $300 \mathrm{mg}$ TMR was incubated with an internal standard (methyl heneicosanoate, Sigma Aldrich Company Ltd., Dorset, UK) at $60^{\circ} \mathrm{C}$ in the presence of $0.4 \mathrm{M}$ sulphuric acid in methanol and toluene as an extraction solvent, for $2 \mathrm{~h}$ (oil) or $3 \mathrm{~h}$ (TMR). Following neutralisation, the resulting fatty acid methyl esters (FAME) in toluene were allowed to stand over sodium sulphate for $30 \mathrm{~min}$ to remove methanol residues before being quantified by gas chromatography (GC; Bruker 350, Bruker, Germany). The GC was equipped with a flame ionisation detector and $100 \mathrm{~m}$ fused silica capillary column (CP-SIL 88, Agilent Technologies, Cheshire, UK), and GC conditions were as published previously (Kliem et al., 2013). Carbon deficiency in the flame ionization detector response for FAME containing 4- to 10-carbon atoms was accounted for using a combined correction factor which also converted FAME to FA (Ulberth et al., 1999). FA were quantified using internal standard peak area, and the results were also expressed as g/100 g FA.

Samples of milk taken just prior to dairy product production (modified and conventional) were analysed for FA profile according to the method of Kliem et al. (2013). Briefly, lipid in $1 \mathrm{ml}$ thawed, warmed (to $40^{\circ} \mathrm{C}$ ) milk was extracted in duplicate using a mixture of diethyl ether and hexane (IDF 1: 2010 [E], International Dairy Federation, 2010, Brussels, Belgium) and extracts were transesterified to FAME according to previously described procedures (Kliem et al., 2013). GC conditions and FAME identification were as described above. Methyl esters not 
available as authentic standards were identified by gas chromatography-mass spectrometry (GC-MS; Thermo Trace GC coupled to ITQ 1100 mass spectrometer using helium as a carrier gas) analysis of 4, 4-dimethyloxazoline (DMOX) derivatives prepared from FAME. Preparation of DMOX derivatives and parameters used for GC-MS analysis were largely in accordance with earlier reports (Shingfield et al., 2006), however a split ratio of 1:14 was used for injection and the online reference library of DMOX electron impact ionisation spectra was http://lipidlibrary.aocs.org. The results were expressed as g/100 g FA. Lipid in $50 \mathrm{mg}$ of conventional and modified butter was first warmed to $40^{\circ} \mathrm{C}$ before $1 \mathrm{ml}$ distilled water (room temperature) added, and mixed vigorously to emulsify the butter fat. Extraction and methylation continued as with milk and the results were expressed as $\mathrm{g} / 100 \mathrm{~g}$ total FA. The lipid in $3 \mathrm{~g}$ of conventional and modified cheese was firstly hydrolysed using $100 \mathrm{ml} 3 \mathrm{M} \mathrm{HCl}$, and the resulting residue filtered through Whatman 1 filter paper prior to drying at $60^{\circ} \mathrm{C}$ for 18 h. The lipid was extracted from the residue using petroleum ether (Brown \& Mueller-Harvey, 1999), and the amount of lipid calculated gravimetrically. The lipid was then gently warmed before $50 \mathrm{mg}$ was transferred to clean glass tubes, and methylation of extracted FA was conducted as for milk and butter.

Nutritional analysis (energy, protein, fat, carbohydrate, ash and moisture) of the dairy products from each cohort was conducted in duplicate by SGS United Kingdom Ltd. (ISO 17025 accredited laboratory; Ellesmere Port, Cheshire, UK). To calculate protein content, the obtained nitrogen result was multiplied by the standard dairy nitrogen conversion factor (6.38) to account for the fraction of non-protein nitrogen in each sample (Maubois \& Lorient, 2016). Micronutrient content analysis (calcium, magnesium, sodium and phosphorus) was conducted in duplicate by inductively coupled plasma-optical emission spectrometry 
(Quaternary Scientific [QUEST], University of Reading, Berkshire, UK). The results were expressed on a dry and fresh weight basis.

\section{Data analysis}

FA composition of all products was analysed using an ANOVA (Minitab17), and included effects of product type, production period, treatment, and period by treatment interactions. Product type was not significant for every FA, so it was removed from the model. Least squares means ( \pm pooled standard error of the mean) are reported, and differences were considered significant at $P<0.01$ to account for multiplicity.

\section{RESULTS}

The FA profile of the high oleic acid sunflower oil used during production P1 and P2 is presented in Table 2. There was a minimal change in FA profile during $\mathrm{P} 2$, when it contained a lower proportion of $c i s-9$ 18:1 and higher proportion of both 16:0 and 18:2 n-6.

The micronutrient composition of the dairy products is presented in Table 3. Although differences between periods could not be statistically analysed due to sample size, there was numerically little difference between the two periods.

The dairy product FA data presented are means across milk, cheese and butter. Lipid from modified dairy products had a lower $(P<0.001)$ total SFA content than lipid from conventional dairy products, including a lower (12 g/100 g FA) concentration of 16:0, but also all SFA $\leq$ 14:0 including branched chain SFA such as 13:0 anteiso, 14:0 iso and 15:0 anteiso (Table 4). In contrast, the concentration of 18:0 was higher $(P<0.001)$ in the modified dairy products. 
223 There was no effect of production period on SFA content apart from 17:0 iso and 20:0 which were more abundant in $\mathrm{P} 1$ products $(P<0.01)$.

Treatment had an effect on both cis- and trans- MUFA (Table 4), with lipid from modified dairy products having a higher $(P<0.001)$ concentration of both. Of the cis-MUFA, cis-9 18:1 was the most abundant (Table 5), and concentration was at least $50 \%$ greater in modified dairy compared with conventional products (Table 5). There were also notable differences in most of the other 18:1 isomers identified, modified products containing higher $(P<0.05)$ lipid

18:1 (the predominant isomer switching from trans-11 18:1 in control products to trans-10 18:1 in modified products). Aside from the 18:1 isomers, there were treatment differences in cis-9 10:1, cis-9 12:1,trans-9 14:1, cis-13 16:1 and cis-9 17:1, all of which were lower $(P<0.01)$ in modified dairy products (Table 4).

Total n-6 and n-3 PUFA concentrations were not different between lipid from conventional and modified products. In contrast, the concentration of total conjugated linoleic acid (CLA) isomers was greater $(P=0.001)$ in modified products (Table 4). Of the non-methylene interrupted 18:2 isomers, cis-9, trans-13 18:2, cis-9, trans-14 18:2 and cis-9, trans-12 18:2 were higher $(P<0.01)$ in concentration in modified products (Table 6). There was an effect of period for cis-9, trans-13, which was more abundant $(P<0.05)$ in $\mathrm{P} 1$ products (Table 6).

\section{DISCUSSION}

245 One of the main challenges of food chain interventions is to maintain a supply of the test food that is consistently different to the conventional product over the period of the study. The current study produced greater volumes of modified dairy products over a longer period of time 
than other published studies (Livingstone et al., 2012). It has been reported previously that the milk FA profile resulting from supplementation with oilseeds can be affected by the chemical composition of other dietary constituents such as starch, or changes in DM intake (Lerch et al., 2012a). Therefore, it is important to demonstrate that these strategies produce similar products over time, for the purposes of both controlled human dietary intervention studies, and also for future commercial application and consumer consumption.

Overall there was little difference in most micronutrient contents of both the conventional and modified milk and dairy products, and this was the same over the two production periods. However, the modified milk had a low fat content (average $28 \mathrm{~g} / \mathrm{kg}$ during period 1, $23 \mathrm{~g} / \mathrm{kg}$ during period 2) prior to processing, which meant it was necessary to standardise the raw conventional milk prior to UHT so that the fat content matched that of the modified milk for the purposes of the human intervention study. Feeding unsaturated oils to dairy cows often suppresses milk fat concentration (Halmemies-Beauchet-Filleau et al., 2011), mainly due to the inhibitory effect of intermediates of rumen biohydrogenation on mammary FA synthesis (Bauman et al., 2011). In the current study, modified cheese was numerically lower (-5.6 g/100 g) in fat content than the conventional cheese, probably due to the raw modified milk being lower in total fat. A study reporting the fat content of Mozzarella cheese made from milk where This suggests that a more suitable approach for production of modified milk on a commercial scale may be to use oilseed supplements that are protected from rumen biohydrogenation. 
Despite being produced across two production periods, there was no effect of production period on the main FA in modified and conventional products. Decreases in milk fat concentrations of de novo-synthesised SFA and increases in 18:0 and cis-9 18:1 following oilseed supplementation were found to be comparable over two consecutive lactations, but changes in most trans-18:1 and 18:2 isomers varied depending on year (Lerch et al., 2012b). This was probably due to differences in starch contents of the experimental diets across the two years (Lerch et al., 2012a). Transient changes in concentration of certain CLA and trans-18:1 isomers have been observed in response to oilseed supplementation over shorter periods of time (Roy et al., 2006). However the current study employed a dietary adaptation period of 4 weeks prior to milk collection, which should have minimised any variation and successfully produced consistent modified milk essential for effective utilisation in the following human intervention study.

There were differences in most individual FA concentrations between conventional and modified products. All short (4:0-10:0) and medium (12:0-16:0) chain SFA were lower in modified products, which was balanced by higher 18:0, cis-9 18:1 and intermediates of biohydrogenation concentrations which supports previous studies (Loor et al., 2002; Kliem et al., 2011). A meta-analysis of recent data reported that the majority of the milk SFA responses to plant oil supplements in dairy cow diets is due to decreases in 12:0, 14:0 and 16:0 concentrations (Kliem \& Shingfield, 2016). This can mainly be attributed to increases in the supply of $\geq 16$ carbon FA leaving the rumen and inhibiting acetyl CoA carboxylase transcription and activity in the mammary gland (Barber et al., 1997).

SFA in modified milk were mostly replaced with cis-9 18:1, which was the predominant FA in the oil supplement. The current study aimed to feed $1 \mathrm{~kg}$ oil/cow/day, which equated to around 
800 g additional cis-9 18:1. In this unprotected oil form it would be expected that some rumen biohydrogenation of cis-9 18:1 would occur as has been reported in detailed in vivo studies (e.g. Loor et al., 2002), however there was a $10 \mathrm{~g} / 100$ g FA difference in cis-9 18:1 concentration between conventional and modified products in the current study, in line with previous studies (Kliem et al., 2011). Milk fat cis-9 18:1 is derived from two sources - diet and endogenous desaturation of 18:0 by mammary epithelial cell $\Delta^{9}$-desaturase. One in vivo study estimated that this enzyme was responsible for almost $60 \%$ of cis-9 18:1 present in milk fat (Mosley \& McGuire, 2007). Dairy products from the current study contained a higher concentration of 18:0 than conventional products, which may have contributed to the increase in milk fat cis-9 18:1.

A proportion of dairy SFA was also replaced by TFA, which are intermediates of rumen biohydrogenation of dietary unsaturated FA (Harfoot \& Hazlewood, 1997). The majority of TFA identified in the current study were trans 18:1 isomers. In vitro studies have established that cis-9 $18: 1$ is converted to a range of trans $18: 1$ isomers during incubation with rumenderived microorganisms (McKain et al., 2010). Furthermore, trans-9 18:1 has been shown to further isomerise during in vitro incubation with rumen bacteria to a range of positional trans 18:1 isomers (Proell et al., 2002). The predominant isomer in the conventional dairy products was trans-11 18:1, but in the modified products, trans-10 18:1 predominated. Trans-10 18:1 is thought to arise as an intermediate of 18:2 n- 6 biohydrogenation in response to changed rumen conditions on certain diets (Bauman et al., 2011), such as those which lower rumen $\mathrm{pH}$ (Palmquist et al., 2005). A recent review concluded that the predominance of trans-10 18:1 in ruminant products is more common than previously thought (Aldai et al., 2013), however very few milk-based studies have resulted in concentrations of trans-10 18:1 at the level observed in the current study. Roy et al. (2006) and Shingfield et al. (2005) both reported relatively high 
concentrations of trans-10 18:1 in milk fat after feeding oilseed supplements (18 and $13 \mathrm{~g} / 100$ g total FA, respectively), with suggested possible reasons being increased supply of 18:2 n-6 and low rumen $\mathrm{pH}$. In the current study, 18:2 n-6 content of the oil was low, so the high trans$1018: 1$ content of modified milk would have been primarily due to isomerisation of $\operatorname{cis}-918: 1$ within the rumen. This was suggested after a similar effect was observed when olive oil (high in cis-9 18:1) was fed to dairy sheep (Gomez-Cortes et al., 2008). Trans-10 18:1 has often been thought partially responsible for milk fat depression, but studies involving abomasally-infused trans-10 18:1 have reported inconsistent results (Lock et al., 2006; Shingfield et al., 2009)

Enriched concentrations of CLA in milk are usually due to an increased supply of 18:2 n-6 or 18:3 n-3 to the rumen, biohydrogenation of which results in increased trans-11 18:1 available to mammary $\Delta^{9}$ desaturase and therefore increased cis-9, trans-11 CLA, the predominant isomer (Palmquist et al., 2005). In the current study modified products had a higher overall CLA concentration than conventional products, but there was no difference in trans-11 18:1. Either desaturation of trans-11 18:1 was extremely efficient, or the increase in CLA concentration observed was due to increases in other CLA isomers.

The observed difference in SFA and MUFA content between conventional and modified products is comparable to that of previous studies (Livingstone et al., 2012). However few previous studies reported a detailed FA profile. The studies of Tholstrup et al. (2006) and Lacroix et al. (2012) were specifically designed to observe the effects of increased ruminantderived TFA, and as such the modified products contained enriched concentrations of trans-11 18:1 in particular. The current study reported a greater concentration of trans-10 18:1 in modified products and the potential for these TFA to impact on CVD risk factors remains to be investigated. 
CONCLUSIONS

349

350

351

352

353

354

355

356

357

358

359

360

361

362

363

364

365

366

367

368

369

370

371

In conclusion, feeding a specially formulated diet containing a high oleic acid sunflower oil to dairy cows over two production periods resulted in dairy products with the same FA profile, lower in SFA (including 12:0, 14:0 and 16:0), and higher in cis- and trans-MUFA (particularly cis-9 18:1 and trans-10 18:1) than conventionally-produced dairy products. Processing the modified milk into UHT milk, butter and Cheddar cheese had minor effects on FA profile. This technique is therefore suitable for the production of modified dairy products, to replicate the FA profile, suitable for use in large-scale human intervention studies, where composition consistency is required over a longer period of time (as is required to assess effects on CVD risk markers). This technique may also suitable for production of modified dairy foods on a commercial scale, although the effect of this dietary strategy on milk fat content should be considered.

\section{ACKNOWLEDGEMENTS}

This study (REplacement of SaturatEd fat in dairy on Total cholesterol, RESET; Clinicaltrials Gov ID: NCT02089035) was funded by the UK Medical Research Council (MRC project number MR/K020218/1), in collaboration with Arla Foods UK. The authors gratefully acknowledge AAK (UK) Ltd. for providing the high oleic sunflower oil in-kind. The authors would like to acknowledge the assistance of Dr J. Guo and Mrs R. Morgan during preparation of samples for analysis, staff at the Centre for Dairy Research for care of the animals, Mrs Val Bines for her expert input into the cheese manufacturing and Mr Chris Bussey for milk processing. The authors declare no conflicts of interest.

\section{REFERENCES}


Aldai N, de Renobales M, Barron L J R and Kramer J K G (2013) Highlight Article summary: What are the trans fatty acids issues in foods after discontinuation of industrially produced trans fats? Ruminant products, vegetable oils, and synthetic supplements. Eur. Journal of Lipid Science and Technology 115 1378-1401.

Barber M C, Clegg R A, Travers M T and Vernon R G (1997) Lipid metabolism in the lactating mammary gland. Biochimica et Biophysica Acta 1347101 - 126.

Bates B, Cox L, Nicholson S, Page P, Prentice A, Steer T and Swan G (2016) National Diet and Nutrition Survey' Results from years 5 and 6 (combined) of the rolling programme (2012/2013 - 2013/2014). Public Health England, London, UK.

Bauman D E, Harvatine K J and Lock A L (2011) Nutrigenomics, rumen-derived bioactive fatty acids, and the regulation of milk fat synthesis. Annual Review of Nutrition 31299 319.

Brown R H and Mueller-Harvey I (1999) Evaluation of the novel Soxflo technique for rapid extraction of crude fat in foods and animal feeds. Journal of AOAC International $\mathbf{8 2}$ 1369-1374.

Gomez-Cortes P, Frutos P, Mantecon A R, Juarez M, de la Fuente M A and Hervas G (2008) Addition of olive oil to dairy ewe diets: effect on milk fatty acid profile and animal performance. Journal of Dairy Science 91 3119-3127.

Halmemies-Beauchet-Filleau A, Kokkonen T, Lampi A M, Toivonen V, Shingfield K J and Vanhatalo A (2011) Effect of plant oils and camelina expeller on milk fatty acid composition in lactating cows fed diets based on red clover silage. Journal of Dairy Science 94 4413-4430.

Harfoot C G and Hazlewood G P (1997) Lipid metabolism in the rumen. Pages 382-426 in The Rumen Microbial Ecosystem. P. N. Hobson and C. S. Stewart, ed. Blackie Academic \& Professional, London, UK. 
Henderson L, Gregory J, Irving K and Swan G (2003) The National Diet and Nutrition Survey: Adults aged 19-64 years vol 2. Energy, Protein, Carbohydrate, Fat and Alcohol Intake. London (UK): TSO.

Kliem K E, Shingfield K J, Humphries D J and Givens D I (2011) Effect of replacing calcium salts of palm oil distillate with incremental amounts of conventional or high oleic acid milled rapeseed on milk fatty acid composition in cows fed maize silage-based diets. Animal 5 1311-1321.

Kliem K E, Shingfield K J, Livingstone K M and Givens D I (2013) Seasonal variation in the fatty acid composition of milk available at retail in the United Kingdom and implications for dietary intake. Food Chemistry 141 274-281.

Kliem K E and Shingfield K J (2016) Manipulation of milk fatty acid composition in lactating cows: Opportunities and challenges. European Journal of Lipid Science and Technology 118 1661-1683.

Lacroix E, Charest A, Cyr A, Baril-Gravel L, Lebeuf Y, Paquin P, Chouinard P Y, Couture P and Lamarche B (2012) Randomized controlled study of the effect of a butter naturally enriched in trans fatty acids on blood lipids in healthy women. American Journal of Clinical Nutrition 95 318-325.

Lerch S, Ferlay A, Pomiès D, Martin B, Pires J A and Chilliard Y (2012a). Rapeseed or linseed supplements in grass-based diets: effects on dairy performance of Holstein cows over two consecutive lactations. Journal of Dairy Science 95 1956-1970.

Lerch S, Ferlay A, Shingfield K J, Martin B, Pomiès D and Chilliard Y (2012b). Rapeseed or linseed supplements in grass-based diets: Effects on milk fatty acid composition of Holstein cows over two consecutive lactations. Journal of Dairy Science 95 5221-5241. 
Livingstone K M, Lovegrove J A and Givens D I (2012). The impact of substituting SFA in dairy products with MUFA or PUFA on CVD risk: evidence from human intervention studies. Nutrition Research Reviews 25 193-206.

Lock A L, Tyburczy C, Dwyer D A, Harvatine K J, Destaillats F, Mouloungui Z and Bauman D E (2006) Trans-10 octadecenoic acid does not reduce milk fat synthesis in dairy cows. Journal of Nutrition 137 71-76.

Loor J J, Herbein J H and Jenkins T C (2002) Nutrient digestion, biohydrogenation and fatty acid profiles in blood plasma and milk fat from lactating holstein cows fed canola oil or canolamide. Animal Feed Science and Technology 9765 - 82.

Markey O, Vasilopoulou D, Kliem K E, Koulman A, Fagan C C, Summerhill K, Wang L Y, Grandison A S, Humphries D J, Todd S, Jackson K G, Givens D I, Lovegrove J A (2017) Plasma phospholipid fatty acid profile confirms compliance to a novel saturated fat-reduced monounsaturated fat-enriched dairy product intervention in adults at moderate cardiovascular risk: a randomized controlled trial. Nutrition Journal DOI $10.1186 / \mathrm{s} 12937-017-0249-2$

Maubois J L and Lorient D (2016) Dairy proteins and soy proteins in infant foods nitrogen-toprotein conversion factors. Dairy Science and Technology 96 15-25.

McKain N, Shingfield K J and Wallace R J (2010) Metabolism of conjugated linoleic acids and 18:1 fatty acids by ruminal bacteria: products and mechanisms. Microbiology 156 $579-588$.

Mosley E E and McGuire M A (2007) Methodology for the in vivo measurement of the $\Delta^{9}$ desaturation of myristic, palmitic and stearic acids in lactating dairy cattle. Lipids $\mathbf{4 2}$ 939-945. 
Noakes M, Nestel P J and Clifton P M (1996) Modifying the fatty acid profile of dairy products through feedlot technology lowers the plasma cholesterol of humans consuming the prodicts. American Journal of Clinical Nutrition 63 42-46.

Oeffner S P, Qu Y, Just J, Quezada, N, Ramsing E, Keller M, Cherian G, Goddick L and Bobe G (2013) Effect of flaxseed supplementation rate and processing on the production, fatty acid profile, and texture of milk, butter, and cheese. Journal of Dairy Science $\mathbf{9 6}$ $1177-1188$.

Palmquist D L, Lock A L, Shingfield K J and Bauman D E (2005) Biosynthesis of conjugated linoleic acid in ruminants and humans. Advances in Food and Nutrition Research $\mathbf{5 0}$ 179-217.

Proell J M, Mosley E E, Powell G and Jenkins T C (2002) Isomerization of stable isotopically labelled elaidic acid to cis and trans monoenes by ruminal microbes. Journal of Lipid Research 43 2072-2076.

Roy A, Ferlay A, Shingfield K J and Chilliard Y (2006) Examination of the persistency of milk fatty acid composition responses to plant oils in cows given different basal diets, with particular emphasis on trans- $\mathrm{C}_{18: 1}$ fatty acids and isomers of conjugated linoleic acid. Animal Science 82 479-492.

SACN (2007) Scientific Advisory Committee on Nutrition. Update on trans fatty acids and health. London (UK): TSO; 2007. 49.

Shingfield K J, Reynolds C K, Lupoli B, Toivonen V, Delmonte P, Griinari J M, Grandison A S and Beever D E (2005) Effect of forage type and proportion of concentrate in the diet on milk fatty acid composition in cows given sunflower oil and fish oil. Animal Science $80225-238$. 
Shingfield K J, Reynolds C K, Hervas G, Griinari J M, Grandison A S and Beever D E (2006) Examination of the persistency of milk fatty acid composition responses to fish oil and sunflower oil in the diet of dairy cows. Journal of Dairy Science 89 714-732.

Shingfield K J, Ahvenjärvi S, Toivonen V, Vanhatalo A, Huhtanen P and Griinari J M (2008) Effect of incremental levels of sunflower-seed oil in the diet on ruminal lipid metabolism in lactating cows. British Journal of Nutrition 99 971-983.

Shingfield K J, Saebo A, Saebo P C, Toivonen V and Griinari J M (2009) Effect of abomasal infusions of a mixture of octadecenoic acids on milk fat synthesis in lactating cows. Journal of Dairy Science 92 4317-4329.

Seidel C, Deufel T and Jahreis G (2005) Effects of fat-modified dairy products on blood lipids in humans in comparison with other fats. Annals of Nutrition and Metabolism 49 4248.

Sukhija P S and Palmquist D L (1988). Rapid determination of total fatty acid content and composition of feedstuffs and faeces. Journal of Agricultural and Food Chemistry 36 1202-1206.

Tholstrup T, Raff M, Basu S, Nonboe P, Sejrsen K and Straarup E M (2006) Effects of butter high in ruminant trans and monounsaturated fatty acids on lipoproteins, incorporation of fatty acids into lipid classes, plasma C-reactive protein, oxidative stress, hemostatic variables, and insulin in healthy young men. American Journal of Clinical Nutrition $\mathbf{8 3}$ 237-243.

Ulberth F, Gabernig R G and Schrammel F (1999). Flame-ionization detector response to methyl, ethyl, propyl and butyl esters of fatty acids. Journal of the American Oil Chemists' Society 76 263-266.

Vafeiadou K, Weech M, Altowaijri H, Todd S, Yaqoob P, Jackson K G and Lovegrove J A (2015) Replacement of saturated with unsaturated fats had no impact on vascular 
496

497

498

499

500

501

502

503

504

505

506

507

508

509

510

511

512

513

function but beneficial effects on lipid biomarkers, E-selectin, and blood pressure: results from the randomized, controlled Dietary Intervention and VAScular function (DIVAS) study. American Journal of Clinical Nutrition 102 40-48.

WHO (2010) FAO, Fats and Fatty Acids in Human Nutrition. Report of an Expert Consultation. Food and Agriculture Organisation of the United Nations. Rome, Italy.

6

7

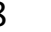


514 Table 1. Ingredients and analysed chemical composition of the cow diet used during 515 production period $1(\mathrm{~g} / \mathrm{kg}$ dry matter $(\mathrm{DM})$ or as stated)

\begin{tabular}{|c|c|}
\hline & $\mathrm{g} / \mathrm{kg} \mathrm{DM}$ \\
\hline \multicolumn{2}{|l|}{ Ingredients } \\
\hline Maize silage & 350 \\
\hline Grass silage & 52 \\
\hline Grass hay & 33 \\
\hline Straw & 33 \\
\hline Wheat by-product ${ }^{1}$ & 86 \\
\hline Concentrate $\operatorname{mix}^{2}$ & 372 \\
\hline Calcium salts of palm oil distillate ${ }^{3}$ & 11 \\
\hline Salt $^{4}$ & 4 \\
\hline Limestone & 4 \\
\hline Minerals and vitamins & 11 \\
\hline High oleic acid sunflower oil ${ }^{5}$ & 43 \\
\hline \multicolumn{2}{|l|}{ Chemical composition } \\
\hline $\mathrm{DM}(\mathrm{g} / \mathrm{kg}$ fresh) & 515 \\
\hline Organic matter & 932 \\
\hline Crude protein & 144 \\
\hline Neutral detergent fibre & 351 \\
\hline Acid detergent fibre & 199 \\
\hline Starch & 212 \\
\hline Oil & 70.0 \\
\hline $\mathrm{ME}(\mathrm{MJ} / \mathrm{kg} \mathrm{DM})^{6}$ & 12.6 \\
\hline \multicolumn{2}{|l|}{ Fatty acids } \\
\hline $16: 0$ & 2.9 \\
\hline 18:0 & 0.9 \\
\hline 18:1 cis-9 & 14.6 \\
\hline $18: 2 n-6$ & 6.1 \\
\hline $18: 3 n-3$ & 0.05 \\
\hline
\end{tabular}

$516{ }^{1}$ CTraffordgold®; KW Alternative Feeds Ltd., Barrow Hill Barns, Andover, SP11 7RG, UK

$517 \quad{ }^{2}$ Containing (g/kg DM): Cracked wheat, 180; Soyabean meal 160; Rapeseed meal, 175;

518 Sugar beet feed, 140; Wheat distillers, 140; Soya hulls, 120; Molasses, 33; Megalac $®, 17$;

519 Urea, 11; Minerals [KW Alternative Feeds Ltd., Barrow Hill Barns, Andover, SP11 7RG,

$520 \mathrm{UK}], 22)$.

$521 \quad{ }^{3}$ Megalac $®$; Volac International Ltd., Royston, Hertfordshire, SG8 5QX, UK

$522{ }^{4}$ Dairy Direct, Church Farm, Bury St Edmunds, IP28 6PX, UK.

$523 \quad{ }^{5}$ AAK (UK) Ltd., Hull, East Yorkshire, HU9 5PX, UK. 
525 Table 2. Fatty acid composition of the high oleic acid sunflower oil used during the two

526 production periods $(\mathrm{g} / 100 \mathrm{~g}$ total fatty acids)

Fatty acid

Production period 1

Production period 2

\begin{tabular}{lcc}
\hline $16: 0$ & 3.6 & 4.1 \\
$18: 0$ & 3.1 & 2.7 \\
$18: 1$ cis-9 & 82.1 & 80.4 \\
$18: 2 \mathrm{n}-6$ & 7.5 & 10.1 \\
$18: 3 \mathrm{n}-3$ & 0.26 & 0.27
\end{tabular}

527

528

529

530

531

532

533

534

535

536

537

538

539

540 
541 Table 3. Micronutrient composition of the modified and conventional dairy products (average across production periods 1 and 2; units as stated,

542 means \pm product s.e.m.)

\begin{tabular}{|c|c|c|c|c|c|c|c|c|c|}
\hline & \multicolumn{3}{|c|}{ UHT milk } & \multicolumn{3}{|c|}{ Butter } & \multicolumn{3}{|c|}{ Cheddar cheese } \\
\hline & Conventional & Modified & s.e.m. & Conventional & Modified & s.e.m. & Conventional & Modified & s.e.m. \\
\hline Energy $(\mathrm{kJ} / 100 \mathrm{~g})$ & 220 & 232 & 6.5 & 3037 & 3024 & 12.1 & 1688 & 1527 & 46.5 \\
\hline Total carbohydrate $(\mathrm{g} / 100 \mathrm{~g})$ & 4.4 & 4.7 & 0.09 & 1.93 & 0.98 & 0.332 & 3.1 & 2.6 & 0.22 \\
\hline Ash (g/100 g) & 0.72 & 0.77 & 0.014 & 1.8 & 1.6 & 0.08 & 4.0 & 3.9 & 0.09 \\
\hline Protein $(g / 100 g)^{1}$ & 3.0 & 3.3 & 0.09 & 0.23 & 0.44 & 0.070 & 23.1 & 26.4 & 1.00 \\
\hline Fat $(g / 100 \mathrm{~g})$ & 2.5 & 2.6 & 0.14 & 81.1 & 81.1 & 0.37 & 33.6 & 28.0 & 1.62 \\
\hline
\end{tabular}




\begin{tabular}{|c|c|c|c|c|c|c|c|c|c|}
\hline Calcium (mg/100 g dry) & 1147 & 1090 & 21.9 & 19.1 & 20.6 & 1.60 & 1242 & 1428 & 87.7 \\
\hline$(\mathrm{mg} / 100 \mathrm{~g}$ fresh $)$ & 126 & 119 & 4.5 & 17.0 & 17.9 & 1.33 & 801 & 911 & 47.0 \\
\hline Magnesium (mg/100 g dry) & 105 & 101 & 1.3 & 2.1 & 2.1 & 0.10 & 46.6 & 47.4 & 0.72 \\
\hline$(\mathrm{mg} / 100 \mathrm{~g}$ fresh) & 11.5 & 11.1 & 0.32 & 1.9 & 1.8 & 0.09 & 30.1 & 30.3 & 0.52 \\
\hline Sodium (mg/100 g dry) & 378 & 417 & 17.8 & 795 & 577 & 72.6 & 1123 & 1187 & 59.3 \\
\hline (mg/100 g fresh) & 41.4 & 45.5 & 2.18 & 707 & 502 & 66.9 & 726 & 760 & 43.1 \\
\hline Phosphorus (mg/100 g dry) & 896 & 819 & 27.5 & 25.4 & 27.0 & 1.73 & 836 & 939 & 51.9 \\
\hline$(\mathrm{mg} / 100 \mathrm{~g}$ fresh $)$ & 98.1 & 89.2 & 3.66 & 22.6 & 23.5 & 1.43 & 539 & 599 & 27.0 \\
\hline
\end{tabular}


545 Table 4. Mean fatty acid composition of the lipid from all modified and conventional dairy products over two production periods ( $\mathrm{g} / 100 \mathrm{~g}$ total 546 fatty acids, least squares means for milk, butter and cheese \pm s.e.m.)

\begin{tabular}{|c|c|c|c|c|c|c|c|c|}
\hline & \multicolumn{2}{|c|}{ Period 1} & \multicolumn{2}{|c|}{ Period 2} & \multirow[t]{2}{*}{ s.e.m. ${ }^{1}$} & \multicolumn{3}{|c|}{$\mathrm{P}^{2}$} \\
\hline & Conventional & Modified & Conventional & Modified & & $\begin{array}{c}\text { Production } \\
\text { period }\end{array}$ & Treatment & Interaction \\
\hline $4: 0$ & 2.9 & 2.2 & 2.9 & 2.1 & 0.06 & 0.668 & $<0.001$ & 0.124 \\
\hline $6: 0$ & 1.8 & 1.1 & 1.9 & 1.0 & 0.04 & 0.732 & $<0.001$ & 0.057 \\
\hline $8: 0$ & 1.11 & 0.62 & 1.14 & 0.54 & 0.030 & 0.420 & $<0.001$ & 0.088 \\
\hline 10:0 & 2.7 & 1.5 & 2.8 & 1.2 & 0.07 & 0.056 & $<0.001$ & 0.033 \\
\hline 10:1 cis -9 & 0.28 & 0.13 & 0.29 & 0.13 & 0.011 & 0.727 & $<0.001$ & 0.547 \\
\hline 11:0 & 0.053 & 0.004 & 0.025 & 0.002 & 0.0138 & 0.329 & 0.031 & 0.375 \\
\hline $12: 0$ & 3.5 & 2.0 & 3.5 & 1.6 & 0.13 & 0.194 & $<0.001$ & 0.133 \\
\hline $12: 1$ cis-9 & 0.10 & 0.05 & 0.10 & 0.05 & 0.005 & 0.893 & $<0.001$ & 0.453 \\
\hline 13:0 & 0.10 & 0.05 & 0.09 & 0.05 & 0.010 & 0.601 & 0.003 & 0.859 \\
\hline 13:0 anteiso & 0.09 & 0.06 & 0.09 & 0.05 & 0.004 & 0.618 & $<0.001$ & 0.418 \\
\hline $14: 0$ & 11.3 & 8.5 & 11.4 & 7.4 & 0.30 & 0.188 & $<0.001$ & 0.077 \\
\hline
\end{tabular}




\begin{tabular}{|c|c|c|c|c|c|c|c|c|}
\hline $14: 0$ iso & 0.08 & 0.07 & 0.09 & 0.07 & 0.005 & 0.669 & 0.008 & 0.842 \\
\hline $14: 1$ cis-9 & 1.02 & 0.95 & 1.04 & 1.01 & 0.041 & 0.366 & 0.231 & 0.663 \\
\hline 14:1 trans -9 & 0.22 & 0.16 & 0.24 & 0.17 & 0.010 & 0.210 & $<0.001$ & 0.686 \\
\hline $15: 0$ & 1.10 & 0.71 & 1.14 & 0.71 & 0.038 & 0.613 & $<0.001$ & 0.585 \\
\hline 15:0 anteiso & 0.43 & 0.38 & 0.42 & 0.35 & 0.008 & 0.021 & $<0.001$ & 0.406 \\
\hline $16: 0$ & 33.3 & 20.9 & 33.8 & 22.2 & 0.69 & 0.220 & $<0.001$ & 0.602 \\
\hline $16: 0$ iso & 0.20 & 0.19 & 0.20 & 0.20 & 0.010 & 0.650 & 0.721 & 0.629 \\
\hline $16: 1$ cis $-9+17: 0$ anteiso & 1.7 & 1.6 & 1.5 & 1.5 & 0.07 & 0.050 & 0.596 & 0.340 \\
\hline $16: 1$ cis-11 & 0.21 & 0.13 & 0.42 & 0.40 & 0.065 & 0.007 & 0.516 & 0.651 \\
\hline $16: 1$ cis-13 & 0.15 & 0.05 & 0.17 & 0.05 & 0.011 & 0.412 & $<0.001$ & 0.417 \\
\hline $16: 1$ trans -9 & 0.03 & 0.10 & 0.10 & 0.05 & 0.101 & 0.377 & 0.001 & 0.640 \\
\hline $17: 0$ iso & 0.33 & 0.36 & 0.29 & 0.31 & 0.012 & 0.008 & 0.073 & 0.588 \\
\hline $17: 0$ & 0.48 & 0.36 & 0.49 & 0.33 & 0.005 & 0.090 & $<0.001$ & 0.013 \\
\hline $17: 1$ cis -9 & 0.20 & 0.16 & 0.20 & 0.15 & 0.003 & 0.333 & $<0.001$ & 0.089 \\
\hline $18: 0$ & 9.6 & 14.0 & 9.4 & 13.0 & 0.32 & 0.089 & $<0.001$ & 0.217 \\
\hline $18: 0$ iso & 0.03 & 0.02 & 0.06 & 0.03 & 0.008 & 0.026 & 0.019 & 0.026 \\
\hline
\end{tabular}




\begin{tabular}{|c|c|c|c|c|c|c|c|c|}
\hline$\sum 18: 1$ trans & 2.8 & 9.4 & 2.6 & 10.2 & 0.30 & 0.348 & $<0.001$ & 0.130 \\
\hline$\sum 18: 1$ cis & 20.0 & 29.6 & 19.3 & 30.3 & 0.74 & 0.994 & $<0.001$ & 0.407 \\
\hline$\sum \mathrm{CLA}^{3}$ & 0.57 & 0.71 & 0.59 & 0.98 & 0.065 & 0.195 & 0.001 & 0.025 \\
\hline$\sum \mathrm{NMI}^{4} 18: 2$ & 2.1 & 2.3 & 2.1 & 2.5 & 0.17 & 0.605 & 0.084 & 0.857 \\
\hline $18: 3 n-3$ & 0.32 & 0.23 & 0.40 & 0.30 & 0.032 & 0.060 & 0.020 & 0.872 \\
\hline $19: 0^{5}$ & 0.10 & 0.10 & 0.08 & 0.08 & 0.016 & 0.326 & 0.970 & 0.966 \\
\hline $20: 0$ & 0.15 & 0.15 & 0.14 & 0.13 & 0.003 & 0.009 & 0.063 & 0.118 \\
\hline 20:1 cis-9 & 0.10 & 0.10 & 0.09 & 0.08 & 0.009 & 0.130 & 0.604 & 0.394 \\
\hline $20: 1$ cis-11 & 0.09 & 0.09 & 0.02 & 0.01 & 0.045 & 0.108 & 0.802 & 0.883 \\
\hline $20: 2 n-6$ & 0.005 & 0.008 & 0.012 & 0.005 & 0.0066 & 0.771 & 0.719 & 0.447 \\
\hline $20: 3 n-6$ & 0.06 & 0.07 & 0.07 & 0.06 & 0.008 & 0.634 & 0.255 & 0.918 \\
\hline $20: 4 n-6$ & 0.10 & 0.07 & 0.10 & 0.06 & 0.007 & 0.625 & 0.001 & 0.300 \\
\hline $20: 5 n-3$ & 0.05 & 0.01 & 0.05 & 0.02 & 0.008 & 0.488 & 0.002 & 0.321 \\
\hline $22: 0$ & 0.05 & 0.08 & 0.05 & 0.08 & 0.007 & 0.851 & 0.003 & 0.370 \\
\hline $22: 2 n-6$ & 0.020 & 0.006 & 0.034 & 0.003 & 0.0119 & 0.727 & 0.082 & 0.554 \\
\hline $22: 5 n-3$ & 0.08 & 0.04 & 0.08 & 0.04 & 0.009 & 0.582 & 0.002 & 0.717 \\
\hline
\end{tabular}




\begin{tabular}{|c|c|c|c|c|c|c|c|c|}
\hline 24:0 & 0.02 & 0.03 & 0.04 & 0.04 & 0.008 & 0.189 & 0.478 & 0.531 \\
\hline$\sum \mathrm{SFA}^{6}$ & 70.3 & 54.3 & 70.9 & 52.2 & 0.97 & 0.479 & $<0.001$ & 0.204 \\
\hline$\sum c i s-\mathrm{MUFA}^{7}$ & 23.0 & 32.2 & 22.5 & 32.9 & 0.67 & 0.932 & $<0.001$ & 0.372 \\
\hline$\sum$ trans-MUFA ${ }^{7}$ & 3.3 & 10.0 & 3.2 & 10.8 & 0.29 & 0.268 & $<0.001$ & 0.125 \\
\hline$\sum$ trans fatty acids & 4.0 & 10.7 & 3.8 & 11.8 & 0.31 & 0.208 & $<0.001$ & 0.082 \\
\hline$\sum \mathrm{n}-3$ PUFA $^{8}$ & 0.63 & 0.48 & 0.72 & 0.59 & 0.054 & 0.096 & 0.033 & 0.791 \\
\hline$\sum \mathrm{n}-6$ PUFA $^{8}$ & 1.7 & 1.9 & 1.9 & 2.0 & 0.18 & 0.547 & 0.578 & 0.865 \\
\hline
\end{tabular}

$547{ }^{1}$ Standard error of the mean for $\mathrm{n}=12$ measurements

$548{ }^{2}$ Refers to the significance of overall effect of period, treatment and their interaction

$549{ }^{3}$ CLA - conjugated linoleic acid

$550 \quad{ }^{4} \mathrm{NMI}$ - non methylene-interrupted

5515 Co-elutes with 18:1 cis-15

$552 \quad{ }^{6}$ SFA - saturated fatty acids

$553 \quad{ }^{7}$ MUFA - monounsaturated fatty acids

$554 \quad{ }^{8}$ PUFA - polyunsaturated fatty acids

555 
556 Table 5. Mean 18:1 isomer composition of the lipid from all modified and conventional dairy products over two production periods ( $\mathrm{g} / 100 \mathrm{~g}$

557 total fatty acids, least squares means for milk, butter and cheese \pm s.e.m.)

\begin{tabular}{|c|c|c|c|c|c|c|c|c|}
\hline & \multicolumn{2}{|c|}{ Period 1} & \multicolumn{2}{|c|}{ Period 2} & \multirow[t]{2}{*}{ s.e.m. ${ }^{1}$} & \multicolumn{3}{|c|}{$\mathrm{P}^{2}$} \\
\hline & Conventional & Modified & Conventional & Modified & & $\begin{array}{c}\text { Production } \\
\text { period }\end{array}$ & Treatment & Interaction \\
\hline cis-9 18:13 & 18.8 & 28.2 & 18.4 & 28.9 & 0.72 & 0.859 & $<0.001$ & 0.439 \\
\hline cis-11 18:1 & 0.61 & 0.81 & 0.44 & 0.70 & 0.048 & 0.023 & 0.001 & 0.522 \\
\hline cis-12 18:1 & 0.22 & 0.16 & 0.21 & 0.19 & 0.016 & 0.467 & 0.042 & 0.318 \\
\hline cis-13 18:1 & 0.09 & 0.16 & 0.08 & 0.11 & 0.017 & 0.103 & 0.017 & 0.364 \\
\hline cis-16 18:1 & 0.06 & 0.06 & 0.05 & 0.04 & 0.005 & 0.091 & 0.454 & 0.294 \\
\hline trans $-6,-7,-818: 1$ & 0.24 & 1.28 & 0.24 & 1.25 & 0.290 & 0.955 & 0.008 & 0.961 \\
\hline trans-9 18:1 & 0.20 & 0.94 & 0.18 & 1.39 & 0.119 & 0.102 & $<0.001$ & 0.082 \\
\hline trans-10 18:1 & 0.36 & 4.01 & 0.41 & 2.49 & 0.413 & 0.113 & $<0.001$ & 0.095 \\
\hline trans-11 18:1 & 1.10 & 0.94 & 0.85 & 1.81 & 0.428 & 0.490 & 0.375 & 0.227 \\
\hline trans-12 18:1 & 0.38 & 1.01 & 0.32 & 1.09 & 0.065 & 0.816 & $<0.001$ & 0.310 \\
\hline trans-15 18:1 & 0.40 & 0.94 & 0.47 & 1.82 & 0.231 & 0.074 & 0.004 & 0.119 \\
\hline
\end{tabular}


trans-16 18: $1^{4}$

0.31

0.35

0.31

0.48

0.024

0.023

0.003

0.026

558

$559{ }^{1}$ Standard error of the mean for $n=12$ measurements

560

${ }^{2}$ Refers to the significance of overall effect of period, treatment and their interaction

561

${ }^{3}$ Co-elutes with 18:1 trans-13/14

$562{ }^{4}$ Co-elutes with 18:1 cis-14.

563

564

565

566

567

568

569

570

571 
Table 6. Mean non-methylene-interrupted 18:2 isomer composition of the lipid from all modified and conventional dairy products over two production periods (all values as $\mathrm{mg} / 100 \mathrm{~g}$ total fatty acids, least square means for milk, butter and cheese \pm s.e.m.)

\begin{tabular}{|c|c|c|c|c|c|c|c|c|}
\hline & \multicolumn{2}{|c|}{ Period 1} & \multicolumn{2}{|c|}{ Period 2} & \multirow[t]{2}{*}{ s.e.m. ${ }^{1}$} & \multicolumn{3}{|c|}{$\mathrm{P}^{2}$} \\
\hline & Conventional & Modified & Conventional & Modified & & $\begin{array}{c}\text { Production } \\
\text { period }\end{array}$ & Treatment & Interaction \\
\hline cis-9, trans-13 18:2 & 182 & 238 & 177 & 334 & 11.4 & 0.004 & $<0.001$ & 0.002 \\
\hline cis-10, trans-14 18:2 & 122.6 & 122.6 & 100.0 & 92.1 & 9.12 & 0.020 & 0.679 & 0.680 \\
\hline cis-9, trans-14 18:2 & 80.4 & 100.8 & 75.4 & 107.9 & 5.83 & 0.861 & 0.002 & 0.330 \\
\hline cis-9, trans-12 18:2 & 33.7 & 50.4 & 26.9 & 54.0 & 3.78 & 0.697 & $<0.001$ & 0.206 \\
\hline trans-9, cis-12 18:2 & 7.5 & 8.2 & 46.0 & 15.5 & 10.80 & 0.067 & 0.205 & 0.187 \\
\hline trans-11, cis-15 18:2 & 122.5 & 105.5 & 66.7 & 134.4 & 23.56 & 0.585 & 0.312 & 0.110 \\
\hline cis-9, cis-12 18:2 & 1449 & 1629 & 1563 & 1686 & 141.3 & 0.561 & 0.316 & 0.845 \\
\hline
\end{tabular}

$574{ }^{1}$ Standard error of the mean for $\mathrm{n}=12$ measurements

5752 Refers to the significance of overall effect of period, treatment and their interaction 